Бобров С. В. к.т.н., доцент;

Беляченко В. В.;

Утюшев М. К.

Центр воєнно-стратегічних досліджень Національного університету оборони України імені Івана Черняховського, Київ

\title{
Методологічні основи підходу до оцінювання результативності та ефективності управління проектами створення автоматизованих систем
}

\begin{abstract}
Резюме: У статті розглянуті різні визначення понять результативності та ефективності управління проектом міжнародних і галузевих стандартів. Показано залежність показників результативності та ефективності управління проектом від сфери діяльності. На прикладі промислового виробництва наведена загальна методика підходу до оцінки результативності і ефективності управління проектом.
\end{abstract}

Ключеві слова: результативність; ефективність; стандарт; показники; управління проектом.

Постановка проблеми. Частіше результати та ресурси оцінюються якісними показниками, які не піддаються кількісному виміру, за певною рейтинговою шкалою у балах, наприклад, методом експертних оцінок. Але іноді це важко зробити, а можна тільки оцінити вимірювання відповідних показників у відносних одиницях [1].

У цих випадках слід говорити про відносну ефективність та результативність по відношенню до будь-яких базових показників або періодів у минулому. Вибір характеристик, за якими визначаються досягнуті результати, проводиться залежно від поставлених перед певним процесом цілей та критеріїв їх досягнення. Для визначення цілі та оцінки ефективності й результативності його реалізації, зазвичай, вибираються найбільш важливі характеристики процесів. Серед різних методів їх вибору найбільш відомим $\epsilon$ “функція розвитку якості" (quality function development - QFD). Оскільки ефективність i результативність пов'язані із запланованими результатами, то частіше говорять про ефективність і результативність досягнення певних цілей. За цілі, зазвичай, обираються такі найважливіші характеристики процесу, які можно вимірювати, наприклад, час на корегування проблеми виявленої користувачами чи споживачами, ефективність, як обсяг використаних непоновлюваних чи поновлюваних ресурсів для отримання результату, результативність (продуктивність) як показники окремої процедури чи процесу в цілому.

Для опису мети кожного процесу встановлюються, зазвичай, кілька характеристик цього процесу і критерії, яким вони мають задовольняти, щоб мета вважалася досягнутою. Це можуть бути зовнішні та внутрішні цілі. Наприклад, зниження кількості виявлених під час технологічного процесу невідповідних зразків матеріалів, зменшення кількості відмов готових виробів при випробуваннях або зменшення кількості рекламацій кінцевих споживачів, досягнення визначеного результату 3 дотриманням норми використання ресурсів. Серед характеристик для оцінювання слід вибирати тільки ті, які істотно впливають на досягнення цілей. Для оцінювання досягнення мети можуть бути використані також споживчі властивості продукції, що виробляється.

Наведені варіанти визначення складових ефективності та результативності потребують необхідності адаптації існуючих показників до реалій проектної діяльності і управління проектом окремої галузі, компанії, організації, формування методичних підходів до оцінки результативності та ефективності управління проектом.

Аналіз останніх досліджень i публікацій [1-3] виявив значне різноманіття підходів до визначення складових оцінки результативності та ефективності управління проектом в цілому, а також проектного менеджменту зокрема. 3 метою адаптації проектного менеджменту до вимог менеджменту якості та особливостей відповідної організації, установи необхідно розробляти методики оцінювання результативності й ефективності системи проектного менеджменту, схему послідовності етапів проведення зазначеної оцінки та перелік показників результативності та ефективності 
процесів та продуктів проекту відповідно до вимог стандартів ISO, галузевих стандартів і настанов.

Метою статті $\epsilon$ розгляд різних визначень понять результативності та ефективності управління проектом міжнародних i галузевих стандартів та залежності показників результативності та ефективності управління проектом від сфери діяльності.

Виклад основного матеріалу. Згідно зі стандартом ISO 9000:2005 [2 (п. 3.2.14)], результативність (effectiveness) - ступінь реалізації запланованої діяльності i досягнення запланованих результатів, ефективність (efficiency) - характеризує співвідношення між досягнутим результатом і використаними ресурсами [2 (п. 3.2.15)].

Система оцінних показників, яка побудована в рамках процесного управління, може структуруватися за чотирма напрямами:

- показники результату діяльності окремих процесів і підприємства в цілому (досягнення запланованих результатів - за обсягом, якістю, номенклатурою і термінами);

- показники ефективності діяльності окремих процесів і підприємства в цілому (відношення отриманих результатів до витрат часу, фінансових й інших ресурсів);

- характеристики продуктів, які виробляються підприємством;

- показники задоволеності клієнтів результатами роботи [3].

Показники результативності $\epsilon$ найголовнішими при виконанні будь-якого проекту, вони є основою оцінювання ефективності проекту в цілому, його окремих процесів, робіт та продукту проекту. Визначення результативності процесів та робіт показує, наскільки певна робота відповідає нормативним актам, настановам та плановим показникам. Оцінювання результативності й ефективності системи проектного менеджменту залежить від проектного портфелю галузі, виробництва, організації (установи). Наприклад, за умов реалізації функціональних процесів одного проекту в промисловому виробництві, система оцінювання результативності та ефективності проектного менеджменту може бути представлена у вигляді алгоритму (рис. 1).

Методологічною основою цього алгоритму $є$ оцінювання ефективності системи проектного менеджменту на підставі оцінки результативності цієї системи і розрахунку узагальнюючого індексу виконання бюджету проекту.

у свою чергу оцінювання

результативності системи управління проектами спирається на визначення показників результативності процесів, якості продуктів та результативності управління процесами.

Показники результативності процесу - це виконання всього переліку робіт для досягнення мети процесу.

Показники якості продукту проекту узгоджені або затверджені документи, які надають можливість перейти до реалізації наступного етапу (процесу).

Показники результативності управління процесом-це показники, які відображають ступінь реалізації запланованих робіт i досягнення запланованих результатів. Для кожного елементу проекту визначається перелік показників результативності (найчастіше експертним методом, виходячи із сутності проектної роботи).

Відповідність фактичного показника результативності до нормативного, за елементом проекту, позначається балом “ 1 ”, максимальна кількість балів дорівнює кількості показників результативності. Результативність розглядається за очікуваними результатами процесу та якості продукту.

Як свідчить світовий досвід основоположною базою сучасних підходів до управління є процесний підхід [3], який передбачає:

- виділення та опис бізнес-процесів;

- призначення “власників” бізнес-процесів;

- розроблення показників ефективності процесів та системи звітності;

- розроблення показників результативності процесів та системи звітності;

- розроблення Положення про систему процесного управління компанії;

- розроблення переліку пріоритетних процесів;

- вдосконалення пріоритетних процесів;

- розроблення опису виконання для пріоритетних процесів;

- розроблення Положень про пріоритетні процеси;

- розроблення схеми організаційної структури;

- вдосконалення організаційної структури та розподіл відповідальності;

- розроблення Положення про організаційну структуру;

- розроблення регламентуючих документів за структурними підрозділами. 


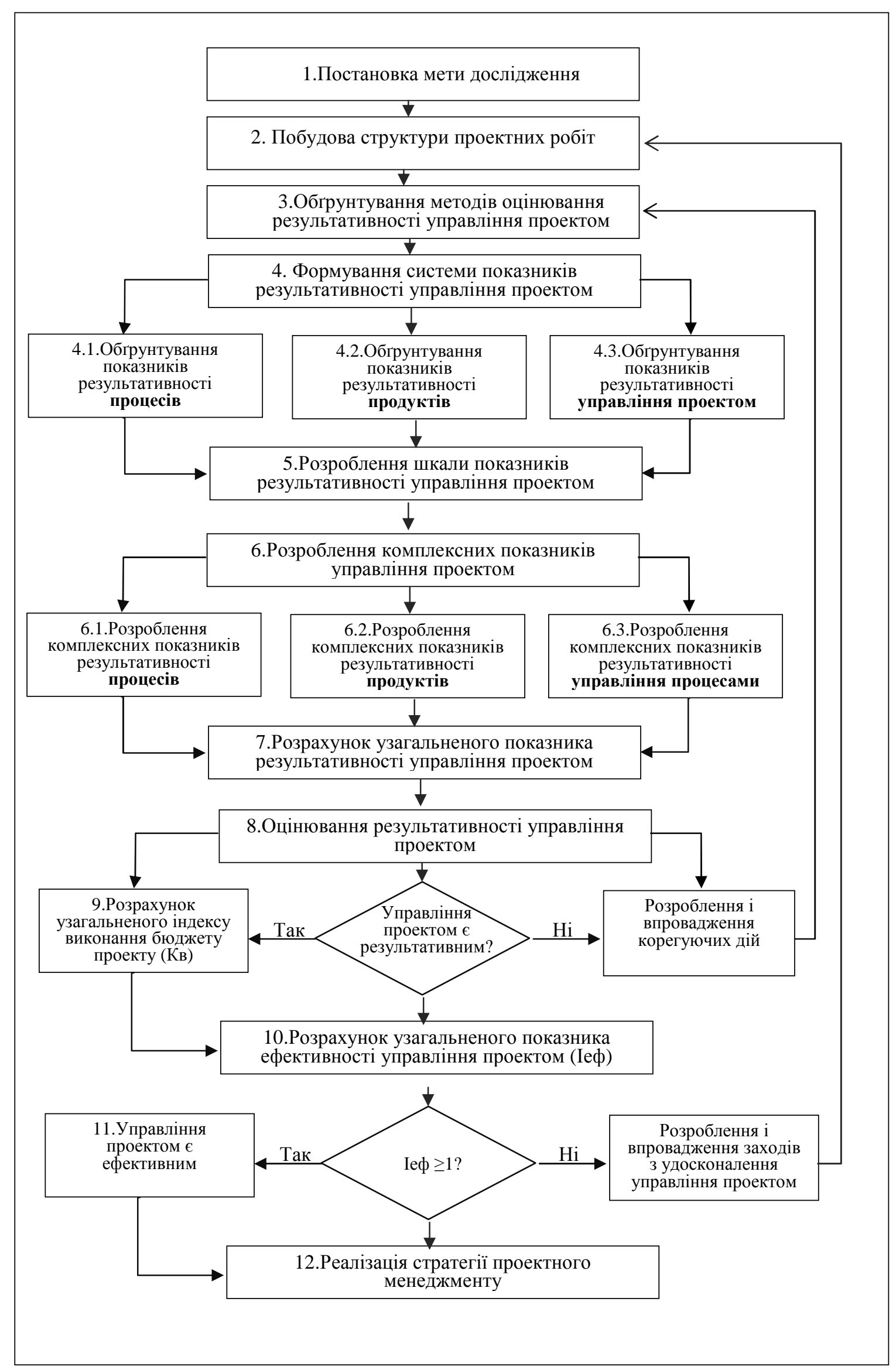

Рис.1. Блок-схема алгоритму оцінки результативності й ефективності проектного менеджменту (за умов виконання одного проекту) 
До результативності процесу можна віднести підсумкові показники за процесом (наприклад, виконання певного обсягу робіт, обгрунтування певного рішення, план розроблення та впровадження, контракти, наявність сировини, технологію розробки та інші), а до результативності продукту документи, договори та угоди, тобто показник результативності за продуктом показує, який продукт було одержано внаслідок впроваджених дій.

Критеріями оцінювання ефективного управління $\epsilon$ множина показників, що характеризують результативність операційних систем або підсистем. Найпоширеніші такі показники [4]:

- економічні - прибуток,

рентабельність, дохід.

- комплексні - продуктивність праці, продуктивність роботи системи управління.

Економічні показники ефективності $\epsilon$ найбільш зрозумілими й активно застосовуються там, де можна чітко виміряти діяльність у грошовому еквіваленті. Звичайно, це виробнича діяльність, де $\epsilon$ норми витрат матеріалів, праці, часу, коштів. Однак увесь результат діяльності було б занадто спрощено зводити тільки до економічних показників.

У контексті теми статті важливо розглянути питання ефективності управління операційними системами [5]. Мета такої системи - забезпечення економічно ефективної реалізації цілей організації. Рівень реалізації цілей і буде загальним показником ефективності цієї системи. При цьому аналізується:

- процес або параметр, який має бути виділений як об'єкт керування;

- зворотний зв'язок або процес виміру результату, який реалізується через ефективну систему контролю;

- система, що визначає відхилення результатів від стандартів;

- точність, швидкість і невисокі витрати будуть запорукою ефективності цього етапу;

- коригувальна й планова системи, які за результатами попередніх етапів роблять зміни діяльності організації убік підвищення загального ефекту їі діяльності.

Для того щоб оцінити рівень реалізації цілей, $\epsilon$ сенс кількісно визначити мету діяльності. Наприклад, часто ціль організації визначається як досягнення певної віддачі на вкладений капітал. Рівень досягнення цієї мети вимірюється просто - порівнянням планового (цільового) показника й фактичного. Якщо фактичний показник більше планового, то система спрацювала ефективно (мета досягнута). Якщо фактичний показник віддачі нижче, чим планували, то необхідно визначити, на яких етапах i в яких системах ефективність не була досягнута, а саме, які підрозділи (ланцюги системи) не виконали своїх цілей.

Висновок. Аналітичні дослідження виявили значне різноманіття підходів до визначення складових оцінки результативності та ефективності управління проектом в цілому, а також проектного менеджменту зокрема.

3 метою адаптації проектного менеджменту до вимог менеджменту якості та особливостей відповідної організації, установи необхідно розробляти методики оцінювання результативності й ефективності системи проектного менеджменту, схему послідовності етапів проведення зазначеного оцінювання та перелік показників результативності процесів та продуктів проекту відповідно до вимог стандартів ISO, галузевих стандартів і настанов.

Розроблені методичні підходи до оцінювання результативності й ефективності системи проектного менеджменту дають змогу виявити помилки у ході реалізації проектів та “вузькі” місця в стратегії управління, що надає змогу уникнути їх у майбутніх проектах та у кінцевому підсумку сприятиме зниженню витрат проектних коштів та часу.

Подальші дослідження доцільно спрямувати на вибір методів оцінювання результативності й ефективності побудови АСУ логістичної системи військового призначення.

\section{СПИСОК ВИКОРИСТАНОЇ ЛІТЕРАТУРИ}

1. ISO 21500: 2012 "Руководство по управлению проектами" [Електронний ресурс]. Режим доступу: http://www.iso.org/iso/ru/home/new s_ index/news_archive/news.htm?refid=Ref1662.

2. ИСО 9000-1: 2005. Стандарты по общему руководству качеством и обеспечению качества. Часть 1. Руководящие указания по выбору и применению [Електронний ресурс]. - Режим доступу: http://www.iso.org.

3. Репин В. В. Возможности процессной системы управления [Электронный ресурс]/В. В. Репин, В. Г. Елиферов. - Режим доступа:

http://www.quality.eup.ru /MATERIALY3/evpp.html.

4. ИСО 10006: 2003. Системы менеджмента качества. Руководство по менеджменту качества при проектировании [Електронний ресурс]. Режим доступа: http://www.quality. eup.ru.

5. ISO 14001: 2004. Системи екологічного менеджменту. Вимоги i керівництво по їх застосуванню [Електронний ресурс]. - Режим доступу: http://www.iso.org . 
Бобров С. В. к.т.н., доцент;

Беляченко В. В.;

Утюшев М. К.

Центр военно-стратегических исследований Национального университета обороны Украины имени Ивана Черняховского, Киев

Методологические основы подхода к оценке результативности и эффективности управления проектами создания автоматизированных систем

Резюме: В статье рассмотрены различные определения понятий результативность и эффективность управления проектом международных и отраслевых стандартов. Показана зависимость показателей результативности и эффективности управления проектом от сферы деятельности. На примере промышленного производства рассмотрена общая методика подхода к оценке результативности и эффективности управления проектом.

Ключевые слова: результативность; эффективность; стандарт; показатели; управление проектом.

\section{S. Bobrov, Ph.D (Technical), assistant professor;}

V. Belyachenko;

\section{Utushev}

Center for Military and Strategic Studies of the National Defence University of Ukraine named after Ivan Cherniakhovskyi, Kyiv

Methodological bases of the approach to the evaluation of the effectiveness and efficiency of project management for the creation of automated systems

Resume: In the article determinations of concepts are considered effectiveness and management efficiency by a project international and industry standards. Dependence of effectiveness and management efficiency is shown by a project from the sphere of activity. On the example of industrial production general methodology of hike is considered to the estimation of effectiveness and management efficiency by a project.

Keyword: effectiveness; efficiency; standard; indexes; project management. 